\title{
PREFACE TO THE PAPERBACK EDITION
}

Since the publication of this book in 1982 we have witnessed the welcome collapse of the Communist system in Eastern and Central Europe and its on-going disintegration in the Soviet Union. "Socialism" is now dead or dying, according to the apologists for capitalism. In truth, however, the demise of this system of state ownership without democracy has made it possible that democratic socialism will be reborn as a movement for social justice and democratic self-rule. This statement may seem paradoxical or at best a forlorn expression of hope in the preface to a book that examines one of the roots of the crisis in democratic socialism which predates the Russian Revolution and the subsequent creation of the Stalinist system and Communist parties.

Although this book examines in detail one particular writer and the movement he inspired, its focus is on the wider phenomenon of an "authoritarian socialism" on the left. It moves between past and present without being, I believe, anachronistic in its analysis or its judgments.

The late Hal Draper coined the phrase "two souls of socialism" and his booklet of that title, an underground classic for democratic socialists, inspired this study.' In his multi-volume work, Karl Marx's Theory of Revalution, Draper dissects the authoritarian, antidemocratic side of the idea of socialism, to which he counterposes Marx's consistent view of socialism as a democratic movement from below. ${ }^{2}$ This is a view of Marx not widely held today, but truth cannot be dependent on popularity nor today's political and intellectual fashions.

1. Hal Draper, "The Two Souls of Socialism," reprinted in New Politics, Vol. 3, no. 1, (whole number 9, n.s.) (1990) 129-156. See also Hal Draper, Socialism From Below, (Atlantic Highlands, NJ: Humanities Press, forthcoming 1992.)

2. Hal Draper, Karl Marx's Theory of Revolution (KMTR), vols. 1-4, (New York: Monthly Review Press, 1977-1991.) Volume 4, Critique of Other Socialisms (1991) analyzes other examples of authoritarian socialism. A collateral volume, The "Dictatorsbip of the Proletariat", from Marx to Lenin (New York, Monthly Review Press, 1989), traces the way in which the concept was tranformed in Lenin and Trotsky's writings to the dictatorship of the party over the working class. Volume 5 of $K M T R$, edited by Ernest Haberkern, will be published in 1992 by Monthly Review Press. It contains a number of chapters which are directly relevant to this subject. A full bibliography of Draper's books and essays may be obtained from the Center for Socialist History, Suite 202, 2633 Etna Street, Berkeley, California 94704. 
Draper's analysis is shared, moreover, by Michael Harrington (who in other respects disagreed with Draper) in his posthumously published Socialism Past and Future. ${ }^{3}$ Harrington's discussion of "authoritarian collectivisms" underscores the revolutionary democratic nature of Marx's socialism. Like Draper, Harrington argues that such authoritarian socialisms, understood as ideologies, not as a social order, must be recognized as part of the dual legacy of the left and, even more important, that the existence of such "socialisms" feeds into support for non-capitalist "bureaucratic collectivist" societies as well as the trend toward the "unsocial socialization" of capitalism. In the twenty-first century, the choice will be between democratic socialization and the authoritarian antidemocratic collectivism that is invading and transforming "private" property and modern corporate capitalism into a global system far beyond the controls of any single nation-state.

For both Draper and Harrington, as well as for the author of this book, the "socialism" of the Soviet-type systems embodied a new form of class society, one neither socialist nor capitalist. And yet, for decades, broad sections of the left, and not only the explicitly pro-Communist left, regarded such systems as socialism-to be embraced or at least to be defended, even after the crimes of Stalin had become common knowledge. For many on the left it was seen as a type of socialism to be held at arm's length, as an alternative version, that was, as the Webbs said, good for the backward Russian masses who lacked a strong democratic tradition, or, in a mirror image of old-fashioned imperialist and racist ideology, especially useful for the backward peoples of third world countries who needed a political class to raise them up.

"Really existing socialism" was the name invented to distinguish this system from the supposedly unrealistic and naive idea of socialism as the incarnation of the democratic transformation of society. Denigration of mere "bourgeois democracy" was the order of the day, as one after another Communist dictator took power and extirpated all democratic self-rule. Elections were unnecessary and a free political life irrelevant as long as there existed a benevolent dictator: a Castro or even a Hoxha. The entirely specious distinction between "economic" and "political" democracy was invented, or reinvented, and we were told that democracy without free1990.)

3. Michael Harrington, Socialism Past and Future, (New York: Plume Books, 
dom of speech, independent political parties, trade unions, etc., was a left wing or socialist idea, or even the embodiment of Marx's thought.

The events in Eastern Europe, first in East Germany and Hungary and then in Poland and Czechoslovakia in the 1950s and 1960s, cracked open this view, but it was many years before the apologists for totalitarianism on the left yielded even partially to the reality of a workers' and popular people's movement against the "socialism" for which they had long apologized, even if sometimes shamefacedly. For those of us who, as democratic socialists, supported the popular overthrow from within of "really existing socialism" in 1989 , just as we had throughout the decades of the cold war, and welcomed the growth of a democratic opposition in Eastern Europe and the Soviet Union, this development provided a chance for a new beginning. Still, not to our surprise, we found quite a few long faces on the left, even among some of those who proclaimed themselves to be democratic socialists. They saw the collapse as a victory for capitalism and not, as it was, the breakdown under popular pressure of a thoroughly undemocratic and incompetent system, clearing the way for a new democratic socialist movement, however difficult or improbable that may appear now. The key concept here was the false idea that even without democracy, state property was progressive and that any social order which was based on state property and was not capitalist had to be a form of socialism and all the more so if its leaders and ideologues labeled it as such. Democracy, political freedom, independent unions, and individual liberty were all irrelevant to this idea of socialism.

In these views can be seen the expression of the authoritarian idea of socialism. This book is about the ideological carriers of an authoritarian socialist ideology within the socialist movement, and the left broadly conceived, whose collectivist anticapitalist ideology aims at a noncapitalist society without democracy. Such currents, it should be emphasized, are not limited to those who call themselves socialists or even view themselves as part of the left. Moreover, I would argue, the seeds of such a social order are present within capitalist society itself, which has become increasingly statist and dominated by collective forms of property. This book, then, is also about democratic control and accountability of both the state and the economy; that is, it is about democratic socialism. One alternative cannot be understood without the other. 
Is any of this relevant in a world in which the "free market" is said to have demonstrated its superiority over all forms of planning and social intervention? Even self-described socialists hail the market and nowhere is "socialism" more reviled and the introduction of the free market seen as the means of social and economic salvation than in Eastern Europe and the Soviet Union. Only in the Soviet Union is socialism defended strongly and there by the still powerful defenders of the old Stalinist order who have the support of the Army and the KGB and members of Communist party. To answer this question it is necessary to turn again to the events which the proponents of the free market and capitalism claim have killed, once and for all, socialism and Marxism along with any vision of democratic planning and social justice.

Understandably, given the false identification of socialism with the system of totalitarian collectivism, the overwhelming majority of the people in the former Communist states have reacted against democratic socialism or social democracy, in favor of a kind of utopian capitalism-a capitalism based on a pure "free market" system which has never existed anywhere except in the imagination of rightwing ideologues. Where, as in Reagan's America or especially in Thatcher's Britain, circumstances allowed the ideologues of the right to run amok, the results have been catastrophic for the welfare of ordinary people. So too, it may safely be predicted, will be the current attempts to replace bureaucratic state planning with markets and to privatize all economic enterprise in Eastern Europe. How "private" the corporate form is is in any case questionable. When we consider that some of the larger investors in Eastern Europe are the Italian and French state corporations or that in the United States there are to be found Chinese Communist state companies owning and running American based enterprises, it becomes clear that the very concept of private property is in need of revision-along the lines suggested by Berle and Means over fifty years ago. ${ }^{+}$

For democracy, through which alone ordinary people can defend their material and spiritual needs and their freedom, the new prophets of the market and privatization, East and West, have little use. The freedom

4. An important contribution to the discussion of the collective nature of modern capitalist property may be found in John McDermott, Corporate Society: Class, Property, and Contemporary Capitalism (Boulder: Westview Press, 1992). See also Adolf Berle and Gardiner Means, The Modern Corporation and Private Property (New York: Macmillan, 1932). 
of which they speak is at best limited; in what may be called really existing capitalism, democracy is eroded, often with the active support of these same proponents of the free market, by powerful centralizing and statist currents. In Britain under Thatcher, state centralization and the attack on democratic institutions and values reached new heights. In the United States, one of the longest-lasting of Reagan's legacies is a Supreme Court led by a Chief Justice who finds that coerced confessions are consistent with the Bill of Rights. Eastern Europe, inundated by missionaries from the right and under pressure from the institutions of world capitalism, is beset by a new authoritarianism which draws on Pinochet's Chile and South Korea as its models of successful free-market economies. In private off-the-record seminars, advocates of the freedom of the market speak frankly about the "authoritarian bureaucratic" road to economic progress in the developing countries and Eastern Europe and admit that it will require the "sacrifice of an entire generation" to achieve the goal of entering the modern global economy. About the really existing violent repression of trade unionists and other opponents of ruthless capitalist exploitation, they shrug their shoulders. The fervor with which markets have been adopted as a means of salvation has a religious quality about it, especially in the case of academics and intellectuals whose advocacy of the healthy rigors of the marketplace for the working class reminds one of other intellectuals' admiration for the utopia of Stalinism.

I must admit my own surprise when, in the course of contact with East European intellectual oppositionists during the 1980s, I began to hear these views. How far removed from reality they were was brought home when more than one of them told me of the importance of turning health care over to the free market. In vain, I pointed to the American experience. Evidence, it is well known, has never deterred those seized by fanaticism, including a fanatical hatred of a discredited order. The British National Health Service, I was repeatedly told, was a failure, rejected by the British people. This canard, carried by the mad monks of the right-wing think tanks who served Mrs Thatcher so well and the British people so poorly, and by doctrinaire American professors whose ideas have contributed to the social and economic decay of their own society, underlines the unthinkingly reactive nature of the popularity of privatization and the market in the former Communist societies as the alternative to democratic socialism. Although it is entirely understandable as an expression of the genuine disgust and hatred inspired by the Com- 
munist system with its invocation of socialism to mask its exploitation and ruin of society, such politics are hardly the basis for the economic salvation of a society to be built on social justice.

The reactive element, a version of the "our enemy's enemy is our friend" syndrome, reminded me strongly of those on the Western left who derided "Westminster-type democracy" and such "bourgeois" institutions as free elections and parties and trade unions, or found charming the leveling qualities of Mao's cultural revolution. The resulting confusion of a social order based on political and economic democracy and social justice with Communism and the subsequent careening toward a new form of injustice and class rule have left a political vacuum which will have to be filled if democracy is to have a chance in the former Communist societies. It is hardly surprising, however, that other authoritarian models of economic order, those about which the right is selectively silent, have begun to fill the vacuum in the heads of those who opposed the former regimes. And, no less important, as recent events in Czechoslovakia and Poland have demonstrated, there is a strong anti-democratic current at work, one heartily supported by certain elements in the Western right whose anti-communism had little to do with an attachment to democracy.

In the original preface to this book, I point to Polish Solidarity as an example of what I meant by a workers' movement from below. Its bravery and tenacity were critical factors in toppling the Communist system through Eastern Europe and the Soviet Union. ${ }^{5}$ I was, however, far too optimistic about its ability to create an alternative politics and social order. Yet Solidarity, although much diminished, has created a powerful force for democracy in Poland, one in contrast to the process of implosion in Czechoslovakia's "velvet revolution," where many elements of the former Communist regime remain in place (especially in the secret police) and whose brave intellectual oppositionists, who acceded to power without a mass democratic movement from below, now face the ironic contradiction of exercising power in a political and social vacuum. Hungary's similar "revolution from above" has also left a vacuum in which genuine

5. For two recent studies of Solidarity emphasizing the creative, democratic role of the working class, see Lawrence Goodwyn, Breaking the Barrier: The Rise of Solidarity in Poland (New York: Oxford University Press, 1991) and Roman Laba, The Roots of Solidarity: A Political Sociology of Poland's Working-Class Democratization (Princeton: Princeton University Press, 1991). 
popular movements and a democratic political culture have yet to appear. Little wonder that in Czechoslovakia we find, as a legacy of this revolution from above, a witch-hunt by a cabal of right-wingers and elements of the former Stalinist political police against Jan Kavan, a key spokesperson for the tiny democratic left. It is the other side of the pressures that lead the new regime to take up the global arms trade as a means of economic survival, just as the former Stalinist regime did. In time, these new dark forces, having fed upon first one victim and then another, will swallow up many of those who now fill its highest offices unless resisted by the creation of a new popular democratic movement from below that can create mass political parties, genuinely independent trade unions and a democratic political culture and offer a program that combines economic change with social justice.

The problem that remains despite the events of 1989-1990, and that must be confronted if the crisis of the idea of socialism today is to be understood and overcome, is the way that many self-described socialists, even democratic socialists and social democrats and those on the left, agreed that the totalitarian systems were and are some form of socialism. Nowadays, of course, it is seen as a bad kind of socialism: in a kind of parody of the sudden amnesia that seized Nazi supporters in Germany after World War II, few on the left admit to ever having favored Stalinism or its Third World counterparts. At any rate, they had their doubts, or so they claim, doubts that did not, unfortunately, extend to support for the democratic opposition or to opposition to the other cold-war camp in the deadly game of thermonuclear threat. Gorbachev's unilateral initiatives were not anticipated by those who believed in the "progressive" nature of Soviet-type societies. The small but significant Western peace groups who called for opposition to the arms race on both sides and who reached out to their counterparts in Eastern Europe were abused for not seeing the progressive nature of Soviet nuclear weapons and armies. In those few instances where Western supporters of the Soviet cold warriors made muted criticisms of the Soviet war policy, it may safely be assumed that at least one of the motives was to assure "deniability" since they rarely translated into any specific politics or led to new thinking about the nature of socialism or the history of the Communist movement.

I look forward to the day when, as a matter not only of historical justice but of confronting the continuing existence of an authoritarian, antidemocratic way of thinking about socialism within the left, a 
thoroughgoing examination of the history of Communism in the Soviet Union and its impact on the Western left is undertaken. A step in this direction is the new history being written in the Soviet Union today, although for the most part what is new in it is a matter of detail which only reinforces the analysis first offered by the independent socialist left since the late 1920s and subsequently by independent scholars.

The "discovery," for example, that Stalin's policies aided the rise of fascism, should remove the last rationale for those who joined or collaborated with the Communist movement and continued their association with it and its policies late into the 1980s. Such a revision of the history of the Communist movement and the way it poisoned the democratic idea of socialism would have little in common with the new revisionist history of the Communist Party in the United States which ignores or misunderstands the pervasive role of Stalinism in the politics and everyday life of the party. If there is an answer to the old question "Why no socialism in America?" it is to be found in no small part in the phenomenon of the hundreds and hundreds of thousands of idealistic people, including many workers, who passed through the Communist movement, only to leave in disillusionment with a "socialism" allied with Hitler or in disgust at the spectacle of tanks crushing worker and student uprisings against their "socialist" masters.

It is tempting to call this an episode in the history of the left which has passed, its lessons learned. Welcome though such a conclusion might be, it is not possible to regard seventy years as an episode and the experience must not be allowed to drop into a convenient memory hole. An entire noncapitalist social order with collateral worldwide social and political movements existed for a substantial part of the twentieth century. Despite its rapid internal collapse, it would be foolish for a number of reasons to dismiss the system and its ideological power or to leave it to celebrants of the "end of history".

First, there exists a powerful and recurring tendency in the history of social movements toward ideological recidivism. Currents run underground for a longer or shorter period, only to reemerge under new circumstances, perhaps with a new name but, more frequently than is usually recognized, with many of the same personnel to give them continuity with their forerunners. Second, that reemergence or reinvention is fueled, of course, by deep trends in society and the economy. Capitalism today tends strongly toward bureaucratic statification and economic collec- 
tivism-the "unsocial socialization" of which Harrington writes-which provides fertile soil for a technocratic or corporatist politics whose "left" face can be found today within European social democratic parties and the many variations of technocratic liberalism. It was this trend toward the self-socialization of capitalism, recognizable even in Marx's day, in which Edward Bellamy's vision of socialism from above, a socialism without democracy, was rooted. One hundred years later, approaching the year 2000, which was the setting for Bellamy's utopian novel, it is this central fact of modern global capitalism which poses the main challenge to a new international labor and socialist movement in the 21 st century. "The revolution we are now living through," Michael Harrington wrote, "is creating a social and political environment that, if it is not subjected to democratic control from below, will subvert the possibilities for freedom and justice that capitalism did so much-if reluctantly-to foster." ${ }^{\text {"T These }}$ are the larger questions about the nature of socialism and of modern capitalism upon which I hope this book sheds light and which make it of continuing relevance to a new generation.

Of no less importance, I think, is the book's contribution to an understanding of a critical period of American history and of a figure whose vision of a noncapitalist society exercised a powerful hold on the imagination and political ideas of several generations of reformers and socialists.

For me, growing up in the 1940s, and for my parents' generation of social democratic liberals, socialists, and Communists, the vision of what socialism was or might be partook directly of Bellamy's utopian novel, which was widely read and used as an educational tract in the large and influential pre-World War I socialist movement. Its republication during the turbulent and radical 1930 s in the mass circulation Modern Library format, with an introduction by Heywood Broun, one of the most popular newspaper columnists of his time, guaranteed it a new audience. It was an audience deeply touched, of course, by illusions about the New Russia: a planned economy without hunger and unemployment in which an industrial army of labor remade the face of an entire society. But Russia was distant, although its hold on the politics and ideas of the American (and non-American) left was overwhelming. The version of socialism offered by Bellamy was easy to assimilate and all the more popular for being a native American product. For a generation experiencing the bitter

6. Harrington, Socialism Past and Future, 7. 
reality of existing capitalism, a vision of a well-run, affluent society shorn of politics, politicians, and all other expressions of conflict, was attractive. As a practical example of Bellamy's industrial army, there was, after all, the New Deal's Civilian Conservation Corps, which drew upon the Plattsburg experiment and found its inspiration in that other prophet of the virtues of military discipline over a soft, commercial civilian society, William James, whose essay on a "moral substitute for war" might have been drawn directly from Looking Backward. Then too, there was the architect of the New Deal's key corporatist policies, Adolf Berle, whose father had been a member of the original Bellamy club in Boston, and whose own intellectual debt to Looking Backward, which he frequently affirmed, can be seen most clearly in his study of The Modern Corporation, where Bellamy's early recognition of the separation of ownership from control and of the importance of a new class of managers was confirmed. And to cap it all, there was Roosevelt's vision of American society: Looking Forward, a widely-understood play on the title of the popular socialist tract. Order, planning, rationality: of what relevance was democracy? How much Bellamy's ideas, or at least those inspired by them, expressed the spirit of the times, can be seen in the wildfire spread during the thirties of Technocracy, which explicitly acknowledged its intellectual debt to Bellamy and Veblen. They may also be found in the ideas of the architect of the first (and only) major step into state ownership and planning, the Tennessee Valley Authority: the life-long Bellamyite, Arthur E. Morgan. Or in the writings of the native American fascist, William Dudley Pelley, who borrowed directly from Looking Backward to describe his authoritarian utopia. All of these and more illustrate the seminal nature of Looking Backward and its impact on American liberalism and the American left and, more broadly, the native anti-capitalist tradition.

These observations underline one of the key themes of this study: that although its main concern is with authoritarian and antidemocratic socialist ideas it is, at the same time, a study of the intellectual origins of these same strains within modern American liberalism. It was not possible to develop this point sufficiently in the book. A full history of this "corporatist" or technocratic side of American liberalism is still to be written. Important beginnings may be found in the work of James Weinstein, Samuel Haber, Arthur Ekirch, Jr., and James Gilbert, just to mention a few of the more important examples. Such a history would fill an important gap, especially in the confused and debased state of American politics 
in the 1990s and in light of the collapse of liberalism today. This is especially true of the origins and evolution of the Progressive reform of the party and electoral system, some elements of which are explored in my discussion of Bellamy's plebiscitarian view of democracy.

It was, of course, as one reviewer insightfully observed, the "Progressive equation between reform and democracy" which I hoped my book would at least undermine, if not fatally wound. The outrage it provoked in another reviewer, a well-known liberal of the Progressive school and advocate of La Follette style "direct democracy" (i.e., plebiscitarian or sham democracy), showed I had hit my target. That equation had been deeply implanted in my own intellectual development. When I first began to study the history of late nineteenth and early twentieth century American socialism and social criticism, the field was dominated, as indeed, was my own outlook, as a child of the liberal thirties and forties, by the Progressive approach, exemplified by Daniel Aaron's Men of Good Hope and, most influentially, Vernon Louis Parrington's Maincurrents in American Thought, which I, like many others of my generation, had absorbed as part of our basic education in American political ideas. (Parrington's later disillusionment, reflected in the incomplete third volume, is rarely noted.) And, of course, the celebration of "the people" against the monopolies-a naive, native populist theme-was reinforced in the 1930 s and after by the Communist popular front historiography.

Certainly Bellamy's views did not fit the equation between reform and democracy, but it took me some time to shake off the conventional framework. The utter falsity of this equation in Bellamy's case, and of the Progressive synthesis as a whole, is now so self-evident to me, and to many more historians today, that I find it hard to believe that generations of historians and other writers were driven to deny or to ignore it, or to dismiss what was so obvious by suggesting that such a judgment was anachronistic. All of this is developed in ample detail in my study. In a way, I feel the close textual analysis, which one reviewer hailed as a triumph of "deconstructionism" (causing me to run to my dictionary to find out what I had done), particularly of Equality, to be the most satisfying part of the book. Reading Equality's message as an auto-critique, I demonstrated that Bellamy himself knew that his earlier views on democracy were those of an American Tory. These were views which he now, ten years later, wished to repudiate. In this way, oddly enough, I rescued Bellamy from his defenders as well as his detractors and clinched the argument about the authoritarian 
message of Looking Backward. One or two reviewers, sadly enough, who either didn't bother to read to the end of the book or whose minds were still in the grip of the Progressive formula, or perhaps whose own ideas about socialism and democracy were uncomfortably close to Bellamy's, failed to see this point, and indeed stoutly defended Bellamy as a democrat and a man of good hope against my hard-hearted analysis.?

A new generation of readers, a far larger one, I hope, will make its own judgment about these matters. I can only say again, by way of conclusion, that a new American history remains to be written. Although a good start has been made by a younger generation of historians which has broken out of the Progressive synthesis, there is a need to think clearly about the issues I have discussed in this essay. The end of the cold war has, I think, the potential to release a creative flood in American politics which could lead to a new democratic movement and a new history. But such a new democratic movement and the creation of a genuine party of opposition require a history that is rigorously truthful and self-critical. Its agenda would begin with the real history of American liberalism and American capitalism while absorbing the lessons which the disastrous history of the various brands of authoritarian and antidemocratic socialism have, or should have, taught us.

Finally, I should like to rededicate this book to the memory of three friends and comrades from whom I learned so much: Hal Draper, who inspired me to write the book and through the years challenged me again and again to think critically about socialist politics; Mike Harrington, from whose books and many discussions over the course of a forty-year friendship I learned more than in any classroom, and from whose example of selfless commitment to socialism and democracy I have always drawn inspiration; and George Rawick, who first interested me in American history and could always offer brilliant insights that would illuminate the way for years. When there is, as I firmly believe there will be, a rebirth of the democratic socialist movement in America, their ideas and their example will serve a new generation as they find their own way to a democratic and socially just society. To these I add my British friends, Lewis Minkin and Patrick Seyd, who helped me to see American history and politics through the prism of the British labor movement; and to Jim

7. For a recent collection of essays on Bellamy see Daphne Patai, ed., Looking Backward, 1988-1888, (Amherst: University of Massachusetts Press, 1988). 
Young, whose own contribution to the study of the two souls of socialism has been an inspiration. A very special acknowledgment is due to Susanne MacGregor, my colleague and friend, who kept urging me to bring out a new edition of this book and has always, by her critical intelligence, helped me to clarify my thinking about basic social and political issues.

(July 1991) 
